\title{
SEASONAL AND ANNUAL CROP EVAPOTRANSPIRATION IN EUROPE OVER 2011-2070
}

\author{
NISTOR, M. M. ${ }^{1,2}$ \\ ${ }^{I}$ School of Civil and Environmental Engineering, Nanyang Technological University \\ 42 Nanyang Avenue, Singapore 639798, Singapore \\ (e-mail: renddel@yahoo.com) \\ ${ }^{2}$ Department of Hydrogeology, Earthresearch Company \\ Cluj-Napoca, Romania (previous affiliation) \\ (Received $2^{\text {nd }}$ Nov 2017; accepted $3^{\text {rd }}$ Apr 2018)
}

\begin{abstract}
The knowledge of evapotranspiration variation is necessary not only for climatology reasons but also for agriculture and hydrology purposes to understand the amount of water resources and its distribution in territory. Here, we present an exhaustive study of spatial distribution of crop evapotranspiration $\left(\mathrm{ET}_{\mathrm{c}}\right.$ ) in Europe, both for seasonal and annual time-shifts related to the present (2011$2040)$ and the future (2041-2070). The method is based on the crop coefficients $\left(K_{c}\right)$ and the climate modes. The seasonal $\mathrm{ET}_{\mathrm{c}}$ varies in Europe from $0 \mathrm{~mm}$ to $772 \mathrm{~mm}$ in the present period and from $0 \mathrm{~mm}$ to $848 \mathrm{~mm}$ in the future period. The annual $\mathrm{ET}_{\mathrm{c}}$ ranges from $0 \mathrm{~mm}$ to $1385 \mathrm{~mm} \mathrm{year}^{-1}$ for the present while the future calculations indicate values which range from $0 \mathrm{~mm}$ to $1496 \mathrm{~mm}_{\text {year }}{ }^{-1}$. Elevated values of annual $\mathrm{ET}_{\mathrm{c}}$ were depicted in the Iberian Peninsula, Balkan Peninsula, Italian Peninsula, and Pannonian basin. These findings are the base for the water resources quantity in Europe for the $21^{\text {st }}$ century, with major help in the hydrological and climatological studies, but also for the agriculture and planning strategies, policymakers' decisions, and considerable scientific contribution.

Keywords: climate change, spatial climate data, evapotranspiration mapping, land cover, crop coefficients, GIS
\end{abstract}

Abbreviations: GIS: geographical information systems, $\mathrm{K}_{\mathrm{c}}$ : crop coefficients, $\mathrm{ET}_{\mathrm{c}}$ : crop evapotranspiration, $\mathrm{ET}_{0}$ : potential evapotranspiration, $\mathrm{K}_{\mathrm{c} \text { ini }}$ : initial season coefficient, $\mathrm{K}_{\mathrm{c} \text { mid }}$ : mid-season coefficient, $\mathrm{K}_{\mathrm{c} \text { end }}$ : end season coefficient, $\mathrm{K}_{\mathrm{c} \text { cold }}$ : cold season coefficient

\section{Introduction}

The changes in the planet's geospheres are continuously also in relations with the climate. A lot of natural systems and artificial conceptions depend on an optimum standard to maintain its functionality. The Earth's climate is warming (Haeberli et al., 1999; Oerlemans, 2005), a fact for which the equilibrium of different entities is triggered in many places, regions, and continents. Increase of the mean air temperature in the last 140 years was observed on the climate trend (IPCC, 2001). Moreover, for the $21^{\text {st }}$ century, an increase in the mean air temperature up to $3{ }^{\circ} \mathrm{C}$ and a decrease of precipitation in different places across the globe were predicted (IPCC, 1996, 2001; Stavig et al., 2005; The Canadian Climate Models, 2014). The obvious findings about global warming have been carried out by studying the glaciers, which are the most sensitive indicators of climate change (Haeberli et al., 1999; Kargel et al., 2005; Dong et al., 2013; Nistor and Petcu, 2015). An increase in the mean sea level was calculated, taking into account the Arctic regions and negative trends of the ice field areas, and ice caps were depicted. However, the impact of climate change on the Earth is not related only to the glaciers melting; it also implies numerous negative outcomes on agriculture, land use, and hydrology. Parmesan and Yohe (2003), Campos et al. (2013) and Prăvălie et al. (2014) indicated the climate change negative impact on ecosystems and on water 
resources. The components of ecosystems and the ecolines could be easily affected by climate change. Due to this reason, many ecosystems and several natural reservations are exposed to major changes in their composition and biodiversity (Nistor, 2013; Nistor and Petcu, 2014).

Regarding the water resources, the negative impact of climate change on surface water has been claimed by scientists to be indicated by the decrease in river discharge and the reduction in runoff (Piao et al., 2010). These facts have a direct impact on water availability (Čenčur Curk et al., 2014). On the other hand, the northern sides of Europe and the Alpine region are faced with the increase of the stream flow discharge in the spring period due to the melting of glaciers and snow, which leads to floods and erosion in many places due to extreme events (IPCC, 2007). Numerous surveys on groundwater and climate change were completed in the last two decades as a consequence of global warming by numerous scientists (Loàiciga et al., 2000; Bachu and Adams, 2003; Brouyère et al., 2004; Nistor et al., 2014; Prăvălie et al., 2014). The majority of them have found that the negative effects of climate change on groundwater recharge were mainly related to the reduction in spring flow discharge and seawater intrusion into coastal areas due to sea level rise. The negative impact of climate change on groundwater quality is related to the increase in groundwater temperature (Taylor and Stefan, 2009; Kløve et al., 2014) and "dissolved oxygen concentrations" (Figura et al., 2011; Kløve et al., 2012, 2014; Haldorsen et al., 2012). Jiménez Cisneros et al. (2014) summarize a series of quantity and quality problems related to climate change in the "IPCC 2014 report". The most important issue of the surface waters and groundwater quantity is directly related to the evapotranspiration amount. Mojid et al. (2015) report the contribution of the impacts of climate change on crop water demand.

In the Southeast Europe region, climate change also negatively affects the evapotranspiration (Nistor et al., 2017a). Several hydrological and climatological studies used the potential evapotranspiration $\left(\mathrm{ET}_{0}\right)$ and actual evapotranspiration for the water balance calculations and water surplus determination (Li et al., 2007; Rosenberry et al., 2007; Gowda et al., 2008). These calculations are more accurate and realistic if the climate data are well combined with the vegetative pattern. This task contributes to find the appropriate values of the $\mathrm{ET}_{\mathrm{c}}$. Allen et al. (1998) and Allen (2000) proposed a method for $\mathrm{ET}_{\mathrm{c}}$ calculation using $\mathrm{K}_{\mathrm{c}}$ values, extracted from the evapotranspiration ratio of the $\mathrm{ET}_{\mathrm{c}}$ and $\mathrm{ET}_{0}$. They calculated the $\mathrm{K}_{\mathrm{c}}$ values for different large varieties of crops, including also the tropics and temperate zones. In the same period, Grimmond and Oke (1999) have conducted a significant research on the $K_{c}$ values related to the urban areas of different cities from the United States. Later, considering Allen et al.'s (1998) method and Grimmond and Oke's (1999) additional work, Nistor and Porumb-Ghiurco (2015) have calculated and completed the spatial distribution of the $\mathrm{ET}_{\mathrm{c}}$ in the EmiliaRomagna region from Italy. They used the climatological data grids to calculate the $\mathrm{ET}_{0}$ and the land cover layer to create the evapotranspiration rate in four seasons. Due to its high applicability, their method has been widely used in $\mathrm{ET}_{\mathrm{c}}$ mapping for many regions of Europe. Thus, Nistor et al. (2017b) found the $\mathrm{ET}_{\mathrm{c}}$ in the Pannonian basin using the climate models of 30 years for the present (1991-2020) and future (2021-2050) and the $\mathrm{K}_{\mathrm{c}}$ values. They observed an increase of $\mathrm{ET}_{\mathrm{c}}$ for the future period due to increase in the mean air temperature. In the mountain area of the Carpathian region, the $\mathrm{ET}_{\mathrm{c}}$ have been calculated by Nistor et al. (2016) and the research findings indicate the increase of $\mathrm{ET}_{\mathrm{c}}$ values for recent decades. These results were connected to the negative climate warming effects on the evapotranspiration and possible decrease in water availability 
for the next half century. Using the groundwater modelling under climate change, the water table levels in Geer Basin from Belgium will be expected to decrease in future (Brouyère et al., 2004). A comprehensive study about the evapotranspiration parameters, based on accurate methods in Western Macedonia from Greece, was done by Ambas and Baltas (2012). The REMO and ALADIN regional climate model simulations have been used by Ladányi et al. (2015) in the Kiskunság National Park from Hungary to investigate the future drought hazard. Anda et al. (2015) and Blanka et al. (2017) have completed the investigations related to evapotranspiration and water management in Central Europe. Kurnik et al. (2014) applied a model of Soil Water Balance European Water Accounting to assess the evapotranspiration of main agricultural regions from Europe. Recently, using the regional fuzzy chain model, Güçlü et al. (2017) calculated the evapotranspiration in the Kingdom of Saudi Arabia. Based on Geographical Information System (GIS) and remote sensing technology, Zhan et al. (2015) have calculated the reference evapotranspiration at a regional scale in China. Ramírez-Cuesta et al. (2017) did the appropriate work in the South of Spain. In the Hungarian-Serbian cross-border area, Fiala et al. (2014) analyzed the severity of drought and its influence on agricultural production.

Considering the threats posed by climate change to agriculture and hydrological resources in one of the most important and diversified continents of the world, our work aimed to calculate ET $_{\mathrm{c}}$ in two time periods (2011-2040 and 2041-2070) based on the high-resolution climate models and land cover data.

\section{Materials and methods}

\section{Study area}

The European continent extends from $34^{\circ} 35^{\prime}$ to $80^{\circ} 42^{\prime}$ latitude $\mathrm{N}$ and from $0^{\circ} 0^{\prime}$ to $8^{\circ} 59^{\prime}$ longitude $\mathrm{W}$ and from $0^{\circ} 0^{\prime}$ ' to $66^{\circ} 42^{\prime}$ longitude $\mathrm{E}$ (Fig. 1 la). Here, we were able to complete the $\mathrm{ET}_{\mathrm{c}}$ only for the main realm of Europe and few islands. The Eastern extremity of Europe and some islands such as Iceland have not been included in this investigation due to a lack of climate data.

Europe is a very varied continent from the relief, climate, and land cover points of view. The northern, western and southern coastal line is unregulated, with many peninsulas and islands. The altitudes of the continent range from slightly below $0 \mathrm{~m}$ in the Netherlands and some lowlands such as the Danube Delta to $4810 \mathrm{~m}$ in Mont Blanc Peak from the Alps Range.

The most extended landforms in Europe are the plains, followed by hilly areas and mountains. Thus, in the eastern part of Europe is the East Europe Plain while in the central and northern sides is located the North European Plain. Other plains are present in different regions of the continent, e.g. the Po Plain extends in the North of Italy, Îlede-France in the North of France, the Romanian Plain in the South of Romania, and the Pannonian basin in the South-central part of Europe.

More important for the land cover biodiversity and for the air mass movement are the mountain ranges too. In the South there are the Alps Mountains which extend on approximately $1000 \mathrm{~km}$ in length; in the central and eastern sides there is the Carpathian Mountains; the elevated southern sides of Europe are represented by the Dinaric Mountain and in the North are located the Scandinavian Mountains. In the West of Europe, between France and Spain, there are the Pyrenees Mountains, in the South of Europe are the Apennines Mountains, while in the North of the British Islands there are 
the Scottish Mountains. In Spain, the high plateau can be found as "Meseta Central", but also other hilly areas extend in Europe, generally interposed between the mountains and plains (e.g. Prealps between the Alps Range and Po Plain, Sub-Carpathians between the Carpathian Range and the Romanian Plain).

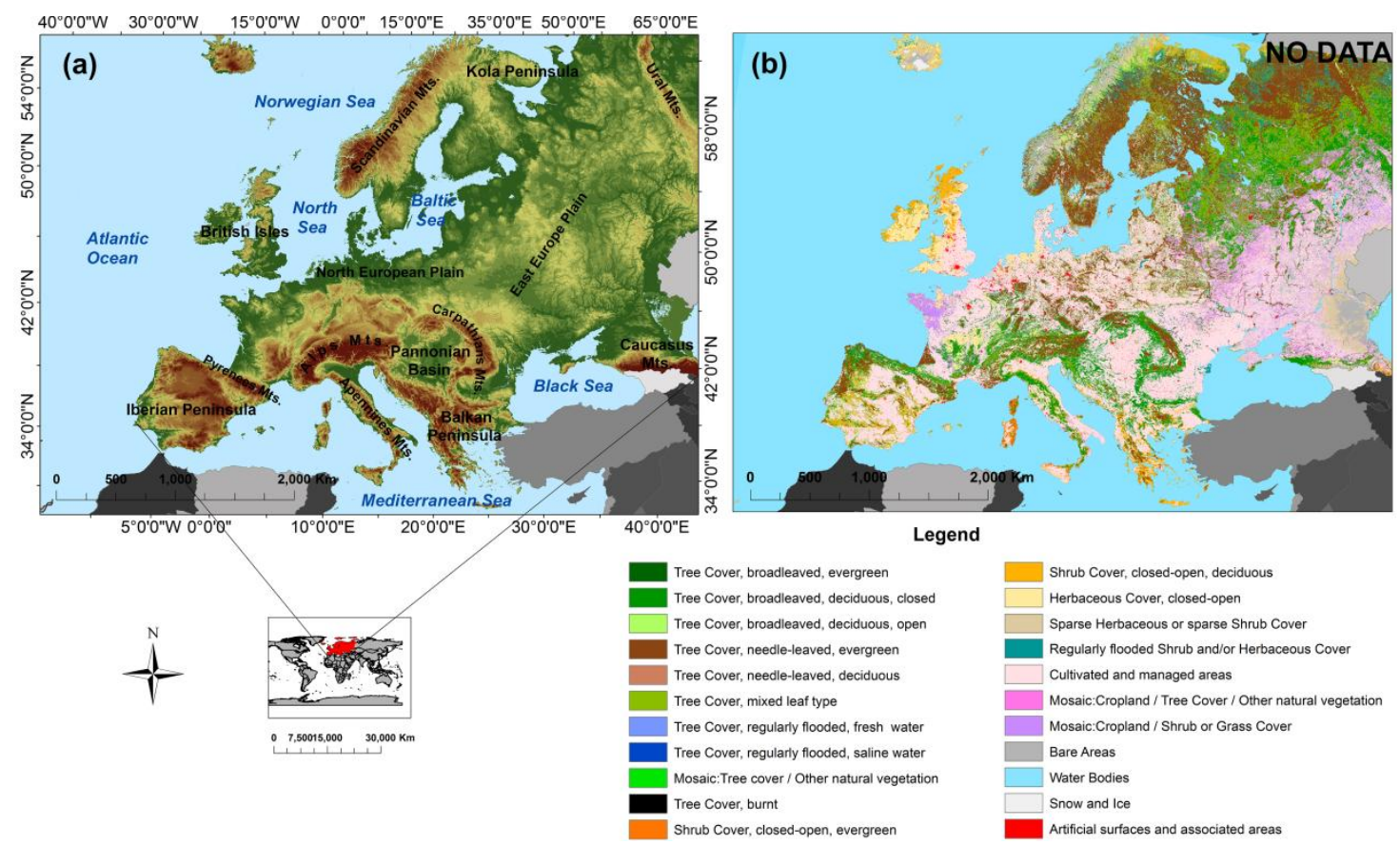

Figure 1. (a) The physical map of European continent and its location on global map. (b) Land cover of Europe

The high extension in latitude and also the presence of the Atlantic and Arctic Oceans in Europe's surroundings are going to influence the different types of climate. In the North of Europe, the climate is Baltic; in the West of Europe there is the ocean influence. In the South of the continent, the Saharan and Mediterranean influences are felt. The continental influences that occur in the East of Europe and the transitional climate between oceanic and continental is more present in the Romanian landscape. The local climates may be depicted in the mountain and near the coastal areas (e.g. in the Alps, in the Carpathians, near the Black Sea, around the Mediterranean Sea). Cfa climate was verified in the central, North-central, Southern and some territories of the southeastern parts of Europe (Kottek et al., 2006). This type of climate is characterized by the warm temperate climate with hot summer and a fully humid period during one year. The Dfa and Dfb climates, which represent the cool climate with hot and warm summers, could be found in the eastern and southeastern sides of Europe. In the Scandinavian Peninsula and northeastern sides, the Dfc cool climate with the cool summers has been identified (Kottek et al., 2006). The South of Europe, mainly the southern sides of the Italian and Balkan Peninsulas, has the Cfc climate. The Csb climate, characterized by dry and warm summers extends to the North of the Iberian Peninsula while the Csa climate, characterized by hot summers and limited precipitation, extends to the South of the Iberian Peninsula. Due to the very low 
temperatures during the winter season, in the Scandinavian Peninsula and in the elevated areas of the Alps Range, the polar tundra climate is easy to find.

In the direct relationship with the climate and relief conditions, the vegetation pattern shows an intense biodiversity in Europe. First, the favourable plain lands and coastal areas are highly recognized for their agriculture lands and urban developed areas. Generally, in the mountains, the coniferous and evergreen forests are growing. In the hilly areas and low mountains, the land cover is mainly composed of mixed and deciduous forests and includes such species as oak (Quercus), beech (Fagus), hornbeam (Carpinus), and elms (Ulmus) (European Environment Agency, 2007). Pasture, transnational woodland, and shrubs predominantly cover the alpine areas. The agricultural crops, hay, and herbaceous vegetation are typically for the lowlands and plain areas. The northern sides of Europe are covered by tundra vegetation. In the North of the Mediterranean Sea, the Mediterranean vegetation of stone pine (Pinus pinea) and maquis vegetation are presented. In the beach areas and drylands such as the South of Europe, the sclerophyllous vegetation is characteristic. The harbour areas, deltas, lagoons, marshes, beaches and dunes are also located in the coastal areas. Figure $1 b$ shows the main land cover of Europe.

\section{Climate data models}

Climate models of the monthly air temperature and annual precipitation at high spatial resolutions have been used for the understanding of Europe's climatic parameters and for the seasonal and annual $\mathrm{ET}_{\mathrm{c}}$ calculations. The models related to the present (2011-2040) and future periods (2041-2070) are the two main datasets for which the $\mathrm{ET}_{\mathrm{c}}$ was computed. Climate projections were obtained from a publicly available database of high resolution climate grids for Europe (http://tinyurl.com/ClimateEU, Hamann et al., 2013). The database builds on the Parameter Regression of Independent Slopes Model (PRISM) to generate monthly precipitation grids for the 1961-1990 climate normal period, generated by Daly (2006). The ANUSplin interpolation method was used to generate monthly temperature grids for the 1961-1990 normal period. Future projections for temperature and precipitation are based on 15 AOGCMs of the CMIP5 multi-model dataset overlayed on the 19611990 baseline grids using the delta method. Further details on the climate database are described by Hamann et al. (2013). Both datasets are bias corrected and calibrated by using an anomaly method. The eastern extremity of Europe does not have available climate data, thus our study does not include this part of the continent.

\section{Land cover data}

A significant dataset in the $\mathrm{ET}_{\mathrm{c}}$ calculation is the land cover layer, which expresses in the best way the vegetation spatial distribution in a certain field. To identify the main crops of Europe and the existing categories of the land cover type, here we used the CORINE Land Cover 2000 database. Even if it dates from 2000s years, CORINE database detailed up to the $3^{\text {rd }}$ level is a raster data $250 \mathrm{~m}$ in spatial resolution elaborated and revised by the European Environment Agency (2016). The main advantages of the CORINE are the details and spatial resolution and the fact that this database covers the whole of Europe better than other versions of the CORINE 2006 and 2012 in that half the territory of Europe is not represented. Moreover, the raster grid of land cover is easy to integrate into the GIS environment. Both land cover and 
climatological data were set at 1 X $1 \mathrm{~km}$ spatial resolution. This resolution was adopted also by Nistor et al. (2016) in their mapping ET $_{\mathfrak{c}}$ study.

\section{Potential evapotranspiration (ET ( $_{0}$}

To calculate the seasonal $\mathrm{ET}_{\mathrm{c}}$, the monthly $\mathrm{ET}_{0}$ was performed both for present and future periods. Due to the worldwide use and efficient performance, the Thornthwaite (1948) method was applied for this study. The monthly raster grid data of mean air temperature for present and future periods have been used to carry out the monthly $\mathrm{ET}_{0}$. Seasonal and annual $\mathrm{ET}_{0}$ were computed from the monthly raster data of $\mathrm{ET}_{0}$.

The Thornthwaite (1948) formula (Eq. 1) is widely considered in the climate, hydrology and agricultural studies (Čenčur Curk et al., 2014; Nistor et al., 2015) but also provides good results at a regional scale (Nistor et al., 2016).

$$
\mathrm{ET}_{0}=16\left(\frac{10 \mathrm{~T}_{\mathrm{i}}}{\mathrm{I}}\right)^{\kappa}
$$

where:

$\mathrm{ET}_{0} \quad$ monthly potential evapotranspiration [mm]

$\mathrm{T}_{\mathrm{i}} \quad$ average monthly temperature $\left[{ }^{\circ} \mathrm{C}\right], \mathrm{ET}_{0}=0$ if $\overline{\mathrm{Tm}}<0$

I heat index (Eq. 2)

$\alpha \quad$ complex function of heat index (Eq. 3)

$$
\mathrm{I}=\sum_{\mathrm{d}_{i=1}}^{12}\left(\frac{T_{i}}{5}\right)^{1.514}
$$

where:

$\mathrm{T}_{\mathrm{i}} \quad$ monthly air temperature

$$
\alpha=6.75 \times 10^{-7} \mathrm{I}^{3}-7.71 \times 10^{-5} \mathrm{I}^{2}+1.7912 \times 10^{-2} \mathrm{I}+0.49239
$$

where:

I annual heat index

\section{Crop coefficients $\left(K_{c}\right)$}

The key to the land cover evapotranspiration research and $\mathrm{ET}_{\mathrm{c}}$ calculation at spatial scale in this approach are the values of $\mathrm{K}_{\mathrm{c}}$. For each type of land cover was assigned a specific $K_{c}$, accordingly with the specific literature (Allen et al., 1998) and previous scientific works (Nistor and Porumb-Ghiurco, 2015; Nistor, 2016a; Nistor et al., 2016, 2017a, b).

Understanding it as being the ratio between $\mathrm{ET}_{\mathrm{c}}$ and $\mathrm{ET}_{0}$, the $\mathrm{K}_{\mathrm{c}}$ could have a slight variation for the same crops, depending on the annual period, local micro-climate conditions, dry or wet state of the Earth surface, latitude, and crop growth (Allen et al., 1998; Grimmond and Oke, 1999; Nistor et al., 2017b). For this reason in the present paper we adopt the standard methodology of the single crop (Allen et al., 1998) and also the values proposed by Nistor (2016a). Allen et al. (1998) published testing values of the $\mathrm{K}_{\mathrm{c}}$ for different zones of the world in the Food and Agriculture Organization Paper 56 report. Regarding the evapotranspiration in the bare soil and urban areas, Grimmond 
and Oke (1999) carried out the $\mathrm{K}_{\mathrm{c}}$ values by measurements in different locations across the United States. Appropriate values of $\mathrm{K}_{\mathrm{c}}$ have been chosen for Europe, considering the latitude as the main factor of relevance.

An important aspect of the spatial representation of the $\mathrm{K}_{\mathrm{c}}$ is coming from the calendar crops growth. For the temperate zone, the plant growth stage has been set in four seasons during one year: (i) initial season from March to May, (ii) the mid-season from June to August, (iii) the end season during September and October, and (iv) the cold season during January, February, November, and December. Nistor (2016b) also inserts one season between initial season and mid-season, the so-called developed season, but in his work the daily $\mathrm{ET}_{\mathrm{c}}$ for a not-so-extensive area was done. Due to the overlapping of the crop calendar (Nistor et al., 2016), at the regional and continental scales the seasonal $\mathrm{ET}_{\mathrm{c}}$ may be divided into four seasons. Thus, in function of the crops and land cover components, the specific values for the initial season coefficient $\left(\mathrm{K}_{\mathrm{c} \text { ini }}\right)$, mid-season coefficient $\left(K_{c}\right.$ mid $)$, end season coefficient $\left(K_{c}\right.$ end $)$, and cold season coefficient $\left(\mathrm{K}_{\mathrm{c} \text { cold }}\right)$ were set for the whole land cover pattern of Europe. Figure 2 indicates the spatial distribution of $\mathrm{K}_{\mathrm{c}}$ on the European continent. Table 1 reports the values of $\mathrm{K}_{\mathrm{c}}$ in the four chosen stages.
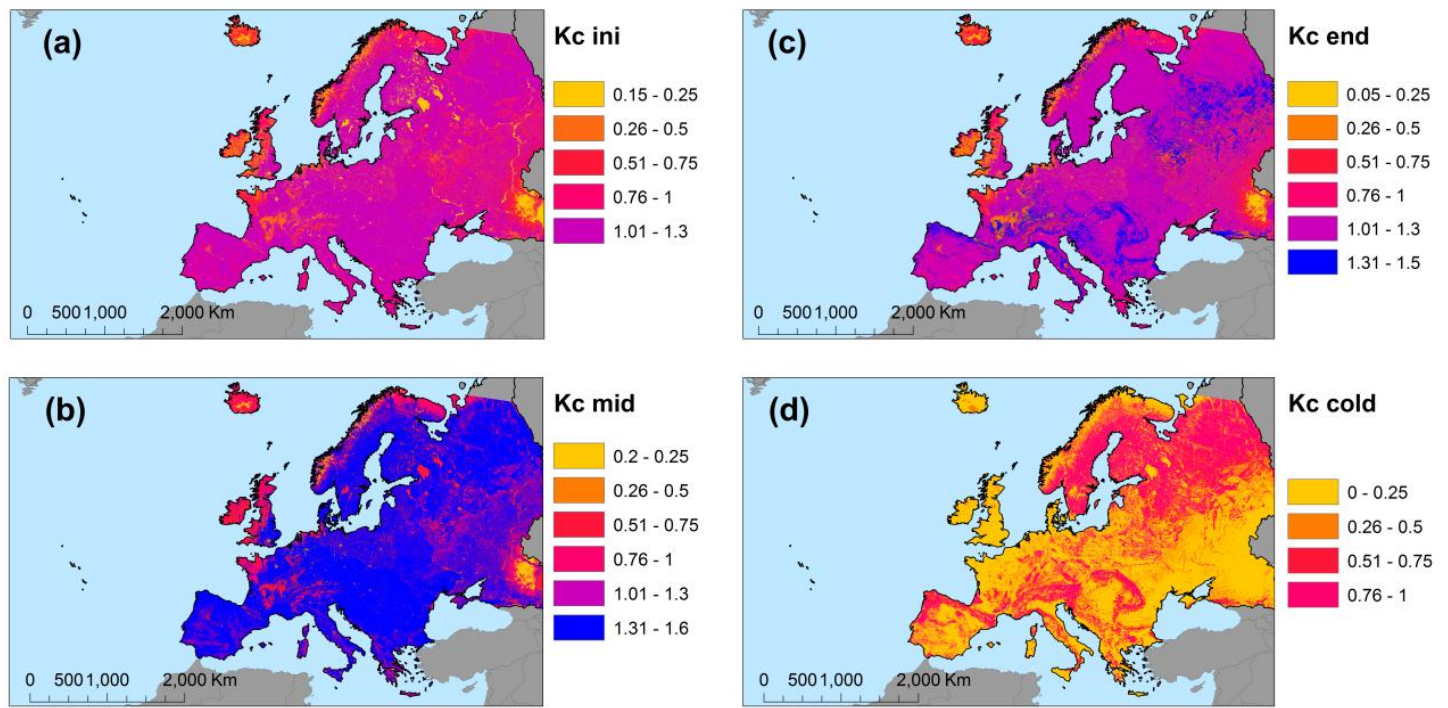

Figure 2. Spatial distribution of $K_{c}$ in Europe related to the land cover. (a) $K_{\text {c ini }}$ for the initial stage. (b) $K_{c \text { mid }}$ for the mid-season stage. (c) $K_{c \text { end }}$ for the end stage. (d) $K_{\text {c cold }}$ for the cold stage

\section{Crop evapotranspiration $\left(E T_{c}\right)$}

The original procedure to calculate the $\mathrm{ET}_{\mathrm{c}}$ is to multiply the $\mathrm{K}_{\mathrm{c}}$ with $\mathrm{ET}_{0}(E q .4)$. The mathematical calculations were completed using the 'Raster Calculator' function, from the ArcGIS 10.3 environment. The powerful spatial data analysis, climatological phenomena mapping and environmental surveys are the main advantages of the Spatial Analyst Tools from the ESRI software (Baltas, 2007; Dezsi et al., 2015; Nistor and Petcu, 2015).

Both seasonal and annual $\mathrm{ET}_{\mathrm{c}}$ for Europe are related to the 2011-2040 and 20412070 periods, with the purpose of observing the effects of climate change on the amount of evapotranspiration during the $21^{\text {st }}$ century. The four seasons of $\mathrm{ET}_{\mathrm{c}}$ have been calculated, multiplying the $\mathrm{K}_{\mathrm{c}}$ of the respective season with the seasonal $\mathrm{ET}_{0}$ from the 
same period stage. Thus, the initial $\mathrm{ET}_{\mathrm{c}}\left(\mathrm{ET}_{\mathrm{c} \text { ini }}\right)(E q .4)$, the mid-season $\mathrm{ET}_{\mathrm{c}}\left(\mathrm{ET}_{\mathrm{c} \text { mid }}\right)$ $(E q .5)$, the end season $\mathrm{ET}_{\mathrm{c}}\left(\mathrm{ET}_{\mathrm{c} \text { end }}\right)(E q .6)$, and the cold $\mathrm{ET}_{\mathrm{c}}\left(\mathrm{ET}_{\mathrm{c} \text { cold }}\right)(E q .7)$ were computed for Europe. Successively, the sum of the seasonal $\mathrm{ET}_{\mathrm{c}}$ was done to calculate the annual $\mathrm{ET}_{\mathrm{c}}$ for the present and the future $(E q .8)$.

$$
\begin{gathered}
\mathrm{ET}_{\mathrm{cini}}=\mathrm{ET}_{0 \text { ini }} \times \mathrm{K}_{\mathrm{cini}} \\
\mathrm{ET}_{\mathrm{c} \mathrm{mid}}=\mathrm{ET}_{0 \text { mid }} \times \mathrm{K}_{\mathrm{c} \text { mid }} \\
\mathrm{ET}_{\mathrm{c} \mathrm{end}}=\mathrm{ET}_{0 \text { end }} \times \mathrm{K}_{\mathrm{c} \text { end }} \\
\mathrm{ET}_{\mathrm{c} \text { cold }}=\mathrm{ET}_{0 \text { cold }} \times \mathrm{K}_{\mathrm{c} \text { cold }} \\
\text { Annual } \mathrm{ET}_{\mathrm{c}}=\mathrm{ET}_{\mathrm{cini}}+\mathrm{ET}_{\mathrm{c} \mathrm{mid}}+\mathrm{ET}_{\mathrm{clate}}+\mathrm{ET}_{\mathrm{c} \mathrm{cold}}
\end{gathered}
$$

\begin{tabular}{|c|c|c|c|c|}
\hline Corine Land Cover 2000 & $\begin{array}{l}\text { Kc ini } \\
\text { season }\end{array}$ & $\begin{array}{c}\text { Kc mid } \\
\text { season }\end{array}$ & $\begin{array}{l}\text { Kc end } \\
\text { season }\end{array}$ & $\begin{array}{l}\text { Ke cold } \\
\text { season }\end{array}$ \\
\hline CLC description & Kclc & Kclc & Kclc & Kclc \\
\hline Tree cover, broadleaved, deciduous, closed & 1.3 & 1.6 & 1.5 & 0.6 \\
\hline Tree cover, broadleaved, deciduous, open (open $15-40 \%$ tree cover) & 1.2 & 1.5 & 1.4 & 0.5 \\
\hline Tree cover, needle-leaved, evergreen & 1.1 & 1.4 & 1.25 & 1 \\
\hline Tree cover, needle-leaved, deciduous & 1.25 & 1.45 & 1.35 & 0.7 \\
\hline Tree cover, mixed leaf type & 1.2 & 1.5 & 1.3 & 0.8 \\
\hline Tree cover, regularly flooded, fresh water (\& brackish) & 1.2 & 1.4 & 1.3 & 0.7 \\
\hline Tree cover, regularly flooded, saline water (daily variation of water level) & 1.05 & 1.3 & 1.2 & 0.6 \\
\hline Mosaic: Tree cover/other natural vegetation & 1 & 1.15 & 1.05 & 0.5 \\
\hline Tree cover, burnt & 0.4 & 0.6 & 0.3 & - \\
\hline Shrub cover, closed-open, evergreen (sparse tree layer) & 0.9 & 1.15 & 1 & - \\
\hline Shrub cover, closed-open, deciduous (sparse tree layer) & 0.8 & 1 & 0.95 & - \\
\hline Herbaceous cover, closed-open & 0.4 & 0.6 & 0.5 & - \\
\hline Sparse herbaceous or sparse shrub cover & 0.6 & 0.8 & 0.7 & - \\
\hline Regularly flooded shrub and/or herbaceous cover & 0.7 & 0.9 & 0.8 & - \\
\hline Cultivated and managed areas & 1.1 & 1.35 & 1.25 & - \\
\hline Mosaic: cropland/tree cover/other natural vegetation & 0.9 & 1.1 & 1.05 & 0.3 \\
\hline Mosaic: Cropland/shrub or grass cover & 0.55 & 0.8 & 0.7 & - \\
\hline Bare areas & 0.15 & 0.2 & 0.05 & - \\
\hline Water bodies (natural \& artificial) & 0.25 & 0.65 & 1.25 & - \\
\hline Snow and ice (natural \& artificial) & 0.48 & 0.52 & 0.52 & 0.48 \\
\hline Artificial surfaces and associated areas & 0.2 & 0.4 & 0.3 & - \\
\hline
\end{tabular}

Table 1. Corine Land Cover classes and representative seasonal Kc coefficients

Kclc - crop coefficient for land cover including: Kc - crop coefficient for plants, Ks - evaporation coefficient for bare soils, $\mathrm{Ku}$ - crop coefficient for urban areas, $\mathrm{Kw}$ - evaporation coefficient for open water. Source: From Allen et al. (1998); Nistor and Porumb-Ghiurco (2015); Nistor and Mîndrescu (2017); Nistor et al. (2017b) 


\section{Results}

Climate models indicate a rise in mean air temperature trend for the current century from $21.4{ }^{\circ} \mathrm{C} \mathrm{(Fig.} \mathrm{3a)} \mathrm{to} 22.8^{\circ} \mathrm{C}$ (Fig. 3b) in Europe. For both the present and future periods, the maximum values of the mean annual temperature could be found mainly in the South of Europe, on the Mediterranean coast, in the West sides of the continent, especially in the Iberian Peninsula, and in some places from the southeastern sides of Europe, near the Black Sea and Marmara Sea. The Scandinavian Peninsula, North of Great Britain Island, and the mountain ranges (the Alps, Carpathians, Dinaric, Pyrenees, and North of Caucasus) are the territories with low values of temperature in Europe (below $6{ }^{\circ} \mathrm{C}$ ). Annual precipitation pattern varies from $160 \mathrm{~mm}$ to $3539 \mathrm{~mm}$ and from $140 \mathrm{~mm}$ to $3487 \mathrm{~mm}$ in the present respective future periods (Fig. 4a, b). The main changes of the spatial distribution of annual precipitation were depicted in the central and eastern sides of the continent. The high values (over $2500 \mathrm{~mm}$ ) of the annual precipitation are frequently in the West of the Scandinavian Peninsula, Alps Range, Dinaric Range and North of the British Island. The lands with low precipitation are located in the South of the Iberian Peninsula, East and South-East of Europe near the Black Sea, and in the South of the Balkan Peninsula. As a consequence of the temperate regime, the annual $\mathrm{ET}_{0}$ reaches values over $1200 \mathrm{~mm} \mathrm{year}^{-1}$ in the present and over $1400 \mathrm{~mm} \mathrm{year}^{-1}$ in the future period. The highest values of annual $\mathrm{ET}_{0}$ were depicted in the southern and western sides of Europe while the lowest values of $\mathrm{ET}_{0}$ were depicted in the northern and northeastern sides of the continent, but also in the mountain areas. Figure 5 shows the annual spatial distribution of $\mathrm{ET}_{0}$ in Europe for the current and future set time periods.
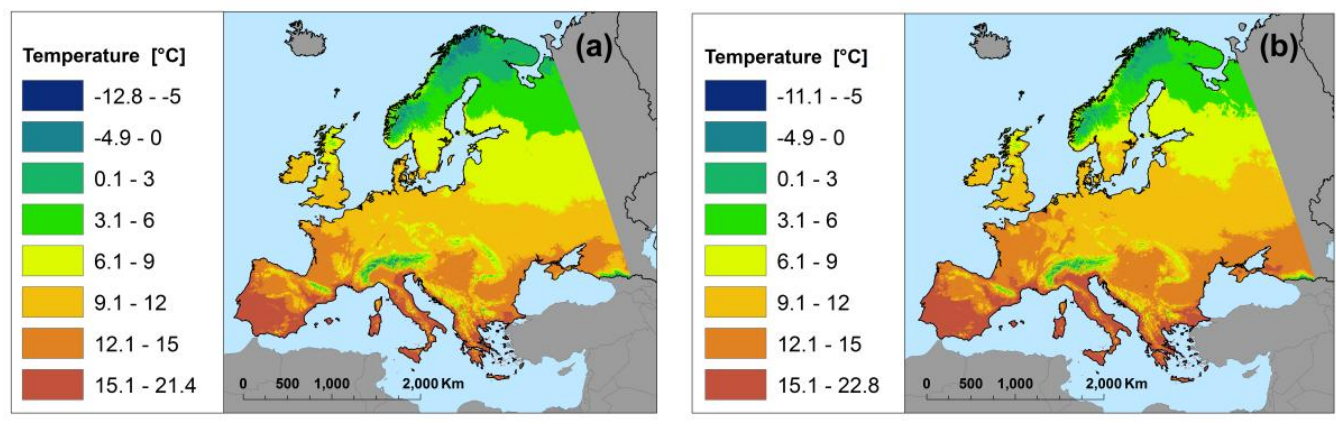

Figure 3. (a) The average of mean annual air temperature between 2011 and 2040. (b) The average of mean annual air temperature between 2041 and 2070
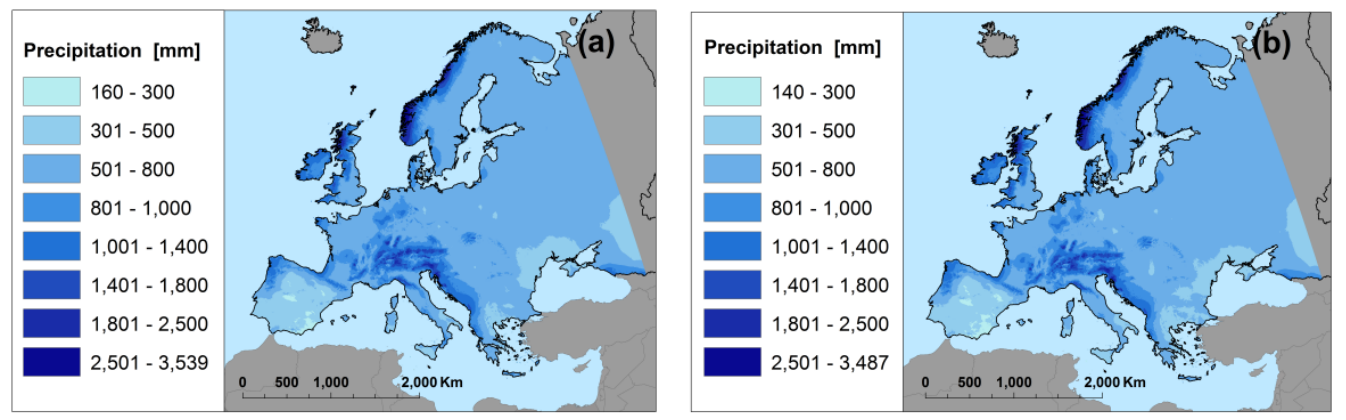

Figure 4. (a) The average of mean annual precipitation between 2011 and 2040. (b) The average of mean annual precipitation between 2041 and 2070 

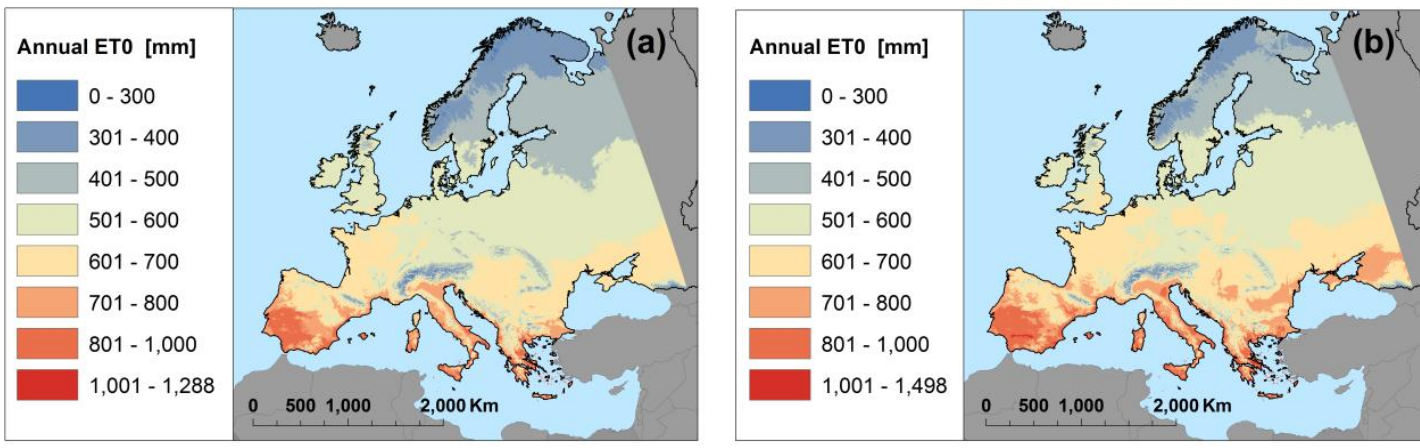

Figure 5. (a) The average annual ET $T_{0}$ between 2011 and 2040. (b) The average annual $E T_{0}$ between 2041 and 2070

Based on climate models and land cover data, the seasonal $\mathrm{ET}_{\mathrm{c}}$ mapping has been completed and analysed for the periods 2011-2040 and 2041-2070. In both times shifts, the seasonal $\mathrm{ET}_{\mathrm{c}}$ calculations illustrate the maximum values during the mid-season, as a consequence of high temperatures and $\mathrm{ET}_{0}$ values in the summer months but also because of the $\mathrm{K}_{\mathrm{c} \text { mid }}$ values, which exceed 1.3 in major parts of the continent.

In the present period $(2011-2040)$ the $\mathrm{ET}_{\mathrm{c} \text { ini }}$ values range from 0 to $240 \mathrm{~mm}$, whereas in the future period (2041-2070) the $\mathrm{ET}_{\mathrm{c} \text { ini }}$ ranges from 0 to $248 \mathrm{~mm}$ (Fig. $6 a$, $b$ ). The few changes between the present and the future may be explained by the contribution of climate change to the increase of $\mathrm{ET}_{0}$ in the spring months (MarchMay). The high values of $\mathrm{ET}_{\mathrm{c} \text { ini }}$ were found in the West of the Iberian Peninsula and in the south-central part of the continent. The lowest values of the ET $\mathrm{c}_{\mathrm{c} \text { ini }}$ are overlapping to the North and northwestern sides of the Scandinavian Peninsula, Alps Range, Pyrenees and Caucasus Mountains. Low ET $_{\mathrm{c} \text { ini }}$ values were depicted also in the West of the British Islands and in the northwestern sides of Europe.
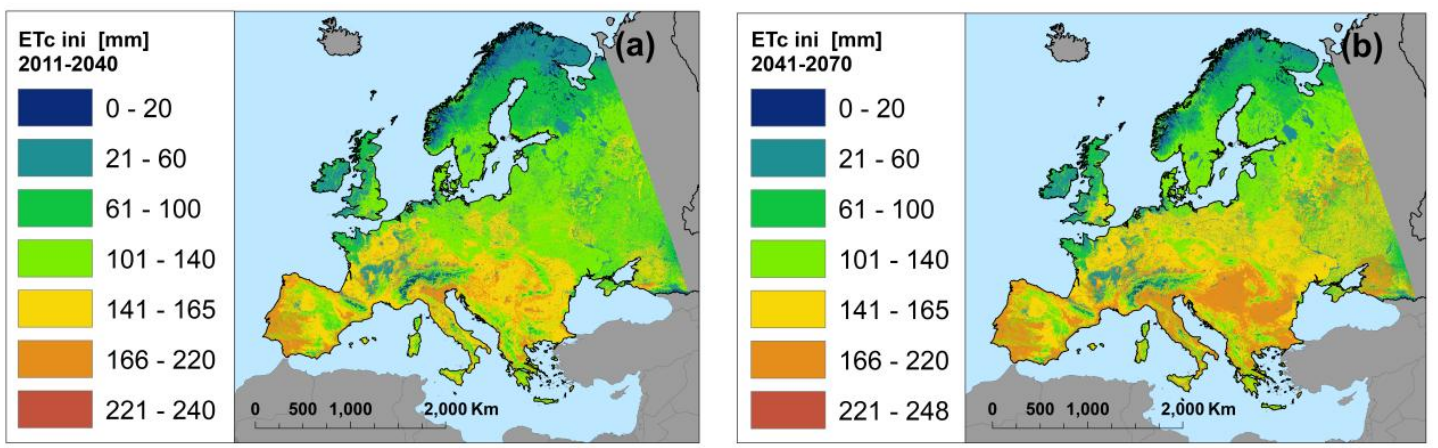

Figure 6. Spatial distribution of $E T_{\text {c ini }}$ in Europe. (a) $E T_{\text {cini }}$ for the initial stage (2011-2040). (b) $E T_{\text {c ini }}$ for the initial stage (2041-2070)

The $\mathrm{ET}_{\mathrm{c} \text { mid }}$ ranges in the present period from 0 to $772 \mathrm{~mm}$, whereas in the future period the $\mathrm{ET}_{\mathrm{c} \text { mid }}$ values range from 0 to $848 \mathrm{~mm}$. The highest values of the $\mathrm{ET}_{\mathrm{c} \text { mid }}$ (over $600 \mathrm{~mm}$ ) were depicted in the South of the Iberian Peninsula and in the South of the Balkan Peninsula. The more significant aspect of the ET $_{\mathrm{c} \text { mid }}$ spatial distribution in Europe is that in the future period the areas of high values extend in a large territory, especially in the South and central sides of the Iberian Peninsula and also on the northern coast of the 
Aegean Sea. The sides with lower $\mathrm{ET}_{\mathrm{c} \text { mid }}$ are found in the elevated mountains of Europe such as the Alps and the Caucasus ranges, in the North and West of the Scandinavian Peninsula, in the central and northern parts of France, and in some sides of northeastern Europe. Figures $7 a$ and $7 b$ illustrate the spatial distribution of $\mathrm{ET}_{\mathrm{c} \text { mid }}$ in Europe.
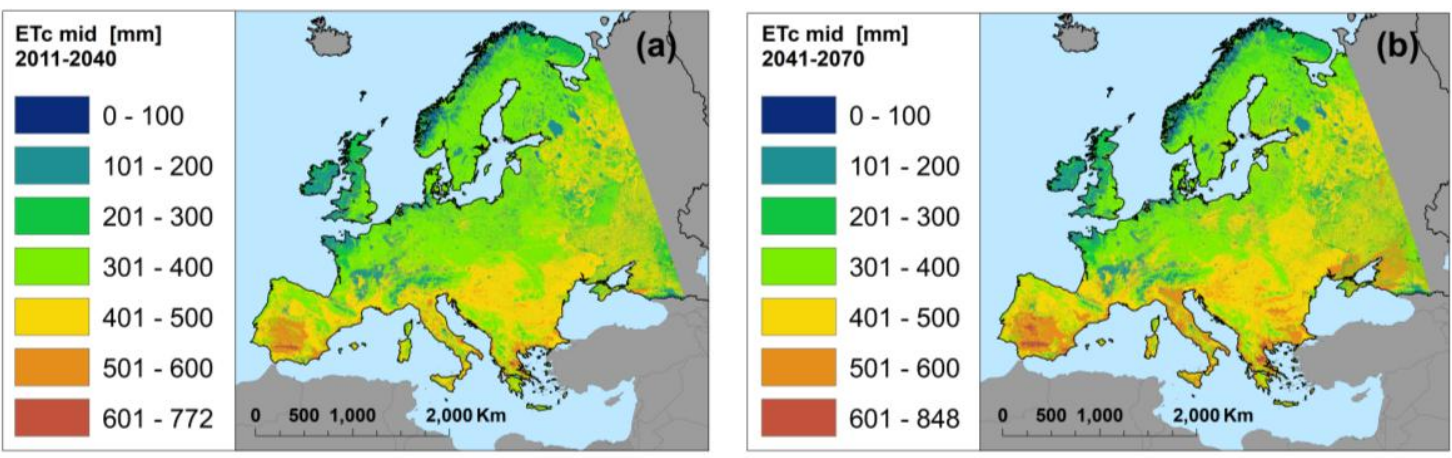

Figure 7. Spatial distribution of $E T_{\text {c mid }}$ in Europe. (a) $E T_{\text {c mid }}$ for the mid-season stage (20112040). (b) $E T_{\text {c mid }}$ for the mid-season stage (2041-2070)

For the present period the $\mathrm{ET}_{\mathrm{c}}$ end varies from 0 to $334 \mathrm{~mm}$ and for the future period the $\mathrm{ET}_{\mathrm{c} \text { end }}$ varies from 0 to $359 \mathrm{~mm}$. The high values of $\mathrm{ET}_{\mathrm{c} \text { end }}$ are located in the West and South of Europe, mainly in the Iberian and Italian Peninsulas, but several places with high $\mathrm{ET}_{\mathrm{c}}$ end values were depicted in the Balkan Peninsula and Mediterranean Islands such as Sardinia, Sicily, and the Aegean Islands. The lower values of $\mathrm{ET}_{\mathrm{c}}$ end are sparsely located in the centre of the continent, the Northern and Eastern parts of Europe, and on the western sides of the British Islands. No significant differences in the spatial distribution pattern between the present and the future are observed. Spatial distribution of $\mathrm{ET}_{\mathrm{c} \text { end }}$ in Europe is shown in Figure $8 a, b$.
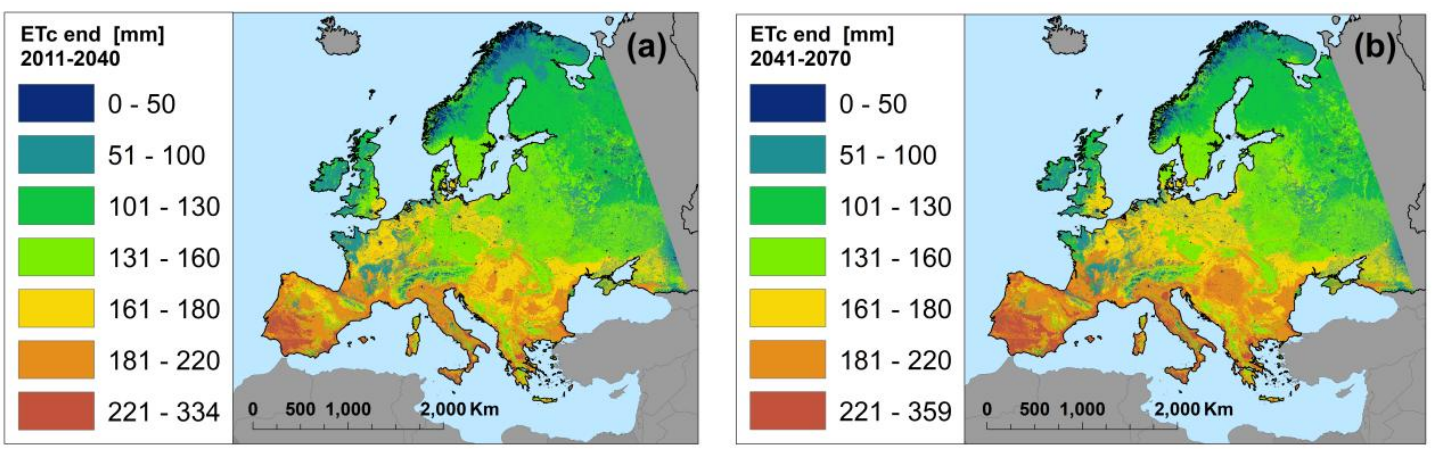

Figure 8. Spatial distribution of ET $T_{\text {cend }}$ in Europe. (a) $E T_{\text {c end }}$ for the end stage (2011-2040). (b) $E T_{\text {c end }}$ for the end stage (2041-2070)

As we expected, the low values of seasonal $\mathrm{ET}_{\mathrm{c}}$ were depicted during the cold season. In the present period the $\mathrm{ET}_{\mathrm{c} \text { cold }}$ ranges from 0 to $178 \mathrm{~mm}$, whereas in the future

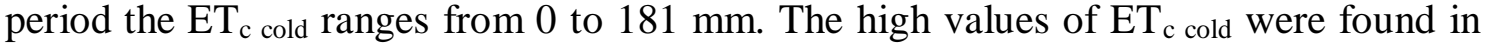
the center, South, South-East and West of Europe. In contrast to other seasons, the spatial distribution of $\mathrm{ET}_{\mathrm{c}}$ overlaps mainly to the elevated areas covered by forest and

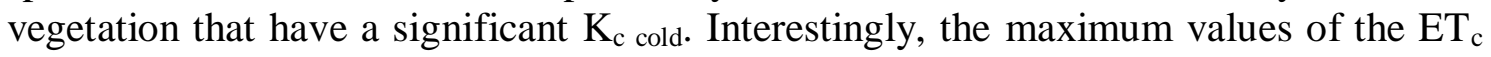


cold could be easily identified in the North, North-West, and North-East of the Iberian Peninsula. Significant values of $\mathrm{ET}_{\mathrm{c}}$ cold are also in the South of the Scandinavian Peninsula, North of the Caucasus Mountains, Carpathian Mountains, and sparsely in the Balkan Peninsula (Fig 9a, b).
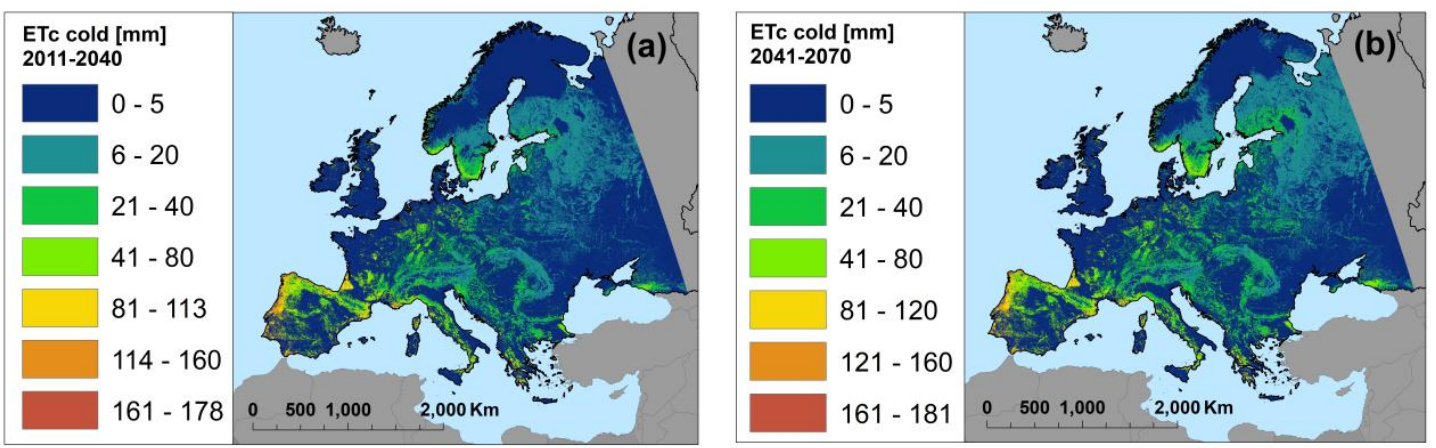

Figure 9. Spatial distribution of ET $T_{\text {c cold }}$ in Europe. (a) $E T_{\text {c cold }}$ for the cold stage (2011-2040). (b) $E T_{\text {c cold }}$ for the cold stage (2041-2070)

The annual $\mathrm{ET}_{\mathrm{c}}$ ranges in the present period from 0 to $1385 \mathrm{~mm}$ year ${ }^{-1}$ and in the future period from 0 to $1496 \mathrm{~mm} \mathrm{year}^{-1}$. The high values (over $1000 \mathrm{~mm}$ ) of the annual $\mathrm{ET}_{\mathrm{c}}$ may be found in the South, West, and South-East of Europe, mainly on the Mediterranean coast. In the central and eastern sides of the continent, the medium values (400 mm year ${ }^{-1}$ to $800 \mathrm{~mm}_{\text {year }}{ }^{-1}$ ) of the annual $\mathrm{ET}_{\mathrm{c}}$ extend, while the low values (below $400 \mathrm{~mm} \mathrm{year}^{-1}$ ) of the annual $\mathrm{ET}_{\mathrm{c}}$ could be found in the North of Europe, the Alps and the Caucasus Ranges, the central land of France, and the West of the British Islands. The elevated values of the annual $\mathrm{ET}_{\mathrm{c}}$ in the future period occupy more territory than in the present, especially in the Iberian Peninsula, Balkan Peninsula, Pannonian basin, and on northern sides of the Black Sea. Figures $10 a$ and $10 b$ show the spatial distribution of the annual $\mathrm{ET}_{\mathrm{c}}$ in Europe.
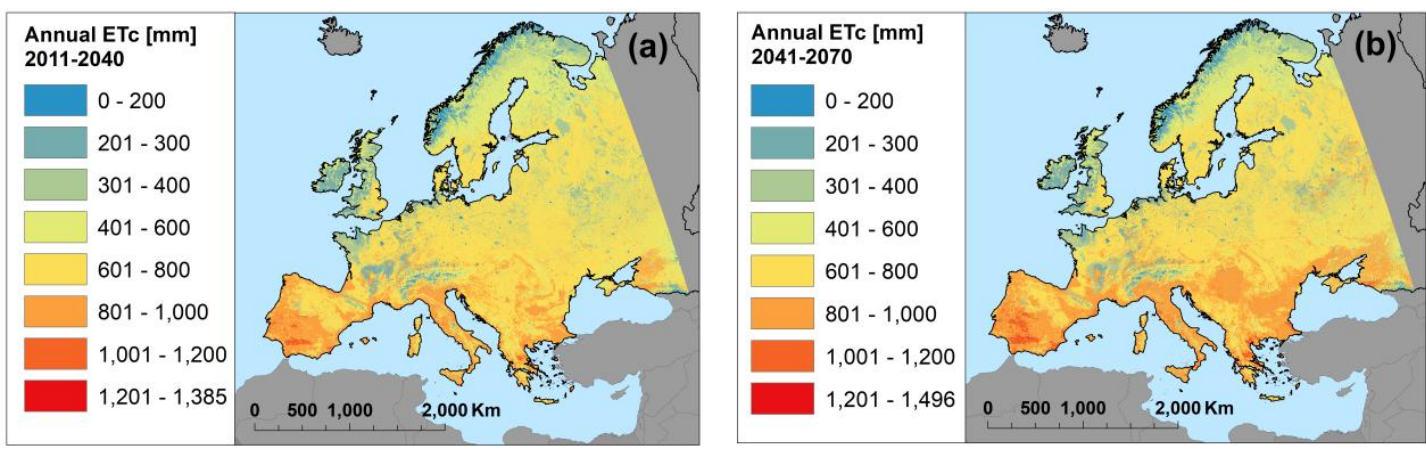

Figure 10. Spatial distribution of annual ET $T_{c}$ in Europe. (a) Annual ET $T_{c}$ for the period 2011 and 2040. (b) Annual ET $T_{c}$ for the period 2041 and 2070

\section{Discussion}

The main goal of the work was to determinate and complete the spatial distribution of the seasonal and annual $\mathrm{ET}_{\mathrm{c}}$ in Europe during the $21^{\text {st }}$ century. Numerous calculations and few presences in the specialty literature of this type of research are 
available. The applied method, based on the land cover and climate models, allow us to bring forward one of the most important climatic parameters at European scale, the seasonal and annual $\mathrm{ET}_{\mathrm{c}}$. Considering the recent climate change (Haeberli, 1999; IPCC, 2001, 2007; Oerlemans, 2005; Nistor, 2014, 2017; Nistor and Petcu, 2015), the first observations about the general climate of Europe have come to affirm the continental warming about $1.4{ }^{\circ} \mathrm{C}$ for the future period (2041-2070). Additionally, the precipitation amount is expected to be slightly lower with a minimum of $50 \mathrm{~mm} \mathrm{year}^{-1}$ and an increase in the annual $\mathrm{ET}_{0}$ by $200 \mathrm{~mm}$ year ${ }^{-1}$ is shown for the $2041-2070$ period. These findings are acceptable while we use the climate models based on the RCP4.5 and not RCP8.5, which may provide the worst scenarios.

The climate variables used in the present study are in line with the findings of existing regional models. Čenčur Curk et al. (2014) and Cheval et al. (2017) carried out the mean air temperature, mean annual precipitation, and annual $\mathrm{ET}_{0}$ for South East Europe. In this part of Europe, Cheval et al. (2017) carried out a maximum difference of $1.4^{\circ} \mathrm{C}$ in the mean air temperature between $1991-2020$ and $2021-2050$ periods, while Čenčur Curk et al. (2014), in their studies about climate change and mitigation of the water resources in South East Europe, illustrate the reduction of the annual precipitation pattern by $60 \mathrm{~mm}$ and increases of the $\mathrm{ET}_{0}$ between the future and present periods. Thus, in the present period Čenčur Curk et al. (2014) indicated values of annual $\mathrm{ET}_{0}$ up to $957 \mathrm{~mm}_{\text {year }}{ }^{-1}$, while in the future they have found $1040 \mathrm{~mm}_{\text {year }}{ }^{-1}$ of annual $\mathrm{ET}_{0}$. In the present work, the values of annual $\mathrm{ET}_{0}$ are more appropriate than the annual values of $\mathrm{ET}_{0}$ carried out by Čenčur Curk et al. (2014).

Best for our contribution to the European researches, up to the present, no studies regarding $\mathrm{ET}_{\mathrm{c}}$ were done on a Europe scale due to the complex procedure of monthly $\mathrm{ET}_{0}$ calculations and $\mathrm{K}_{\mathrm{c}}$ integration. Few regional works of $\mathrm{ET}_{\mathrm{c}}$ bring forward the effects of climate change on evapotranspiration. Annual values of $\mathrm{ET}_{\mathrm{c}}$ obtained in the present paper are comparable to the values obtained by Nistor et al. (2017b) in South East Europe. They determined the annual ET $_{\mathrm{c}}$ in two time shifts (1991-2020 and 20212050) in which the maximum values of the annual $\mathrm{ET}_{\mathrm{c}}$ registered $1297 \mathrm{~mm}$, respective $1410 \mathrm{~mm}$. More than this, even if Nistor et al. (2017b) have used regionally coupled models (RCMs) for the climate data, the spatial distribution of high values of $\mathrm{ET}_{\mathrm{c}}$ were found in the South of the Balkan Peninsula, like in the present paper. Appropriate results of the annual $\mathrm{ET}_{\mathrm{c}}$ at European scale are in line with annual $\mathrm{ET}_{\mathrm{c}}$ carried out at the regional scale of the Pannonian basin and Carpathian region by Nistor et al. (2017a), respective Nistor et al. (2016). In the first case, the maximum annual values of $1083 \mathrm{~mm}$ for the present period (1991-2020) and $1148 \mathrm{~mm}$ for the future period (20212050) have been calculated for the $\mathrm{ET}_{\mathrm{c}}$ in the Pannonian basin, while in the Carpathian region the annual $\mathrm{ET}_{\mathrm{c}}$ reached $1019 \mathrm{~mm}$ in the period of 1991-2010. At the European scale, in these territories the annual $\mathrm{ET}_{\mathrm{c}}$ values indicate $600-1000 \mathrm{~mm}$ for the present and 800-1200 mm for the future. Based on the historical data of the 1991-2005 period, Nistor and Porumb-Ghiurco (2015) have found maximum values of annual $\mathrm{ET}_{\mathrm{c}}$ around $1118 \mathrm{~mm}_{\text {year }}{ }^{-1}$ in the Emilia-Romagna region from Italy, while in our study, the annual $\mathrm{ET}_{\mathrm{c}}$ for the same region indicates 1000-1200 $\mathrm{mm} \mathrm{year}^{-1}$.

Between present and future periods, the seasonal $\mathrm{ET}_{\mathrm{c}}$ indicates higher difference in the mid-season and end season. Thus, an increase from $772 \mathrm{~mm}$ to $842 \mathrm{~mm}$ it was calculated during the mid-season for 2011-2040 respective 2041-2070. Regarding the end season, the values of $\mathrm{ET}_{\mathrm{c} \text { end }}$ are expected to increase between present and future from $334 \mathrm{~mm}$ to $359 \mathrm{~mm}$. These results may have drastic influences on the hydrology of Europe but also 
on the biodiversity of the territory mainly in the summer and early autumn. The negative impact of the current and future climate in Europe on the evapotranspiration is quite alarming, especially for the western and southern sides of Europe. The above-mentioned comparison with the previous surveys in various regions of Europe is a good outcome in agreement with the European map of $\mathrm{ET}_{\mathrm{c}}$. However, our work has some limitations, which are closer to the direct evapotranspiration measurements that can improve the results, but only in the local sites. To generalize the field measurements of each crop type to the whole of Europe is not a suitable method for the fact that we have chosen to integrate the standard values proposed by Allen et al. (1998), Nistor and Porumb-Ghiurco (2015), Nistor (2016), Nistor et al. (2017a). Moreover, these shortcomings do not affect the research because the study was done on a continental scale and the land cover and climate data are represented using high resolutions.

The results of the advanced calculations of the seasonal $\mathrm{ET}_{\mathrm{c}}$ related to the four stages show not only an increase in the $\mathrm{ET}_{\mathrm{c}}$ amount for all stages but also the widening of the territories with high values. In the initial season, the higher values of $\mathrm{ET}_{\mathrm{c} \text { ini }}$ are often found in warm areas with the land covered by broad-leaved forests, cultivated lands, and managed agricultural areas. The herbaceous areas and croplands backed with the high mean air temperature indicate the highest values for the $\mathrm{ET}_{\mathrm{c} \text { mid }}$ season such as in the South of the Iberian Peninsula and east-central sides of Greece. During the $\mathrm{ET}_{\mathrm{c}}$ end season, tree cover, needle-leaved forest, deciduous forests and agricultural areas from West, South and South-East sides of Europe represent the main vegetation with high evapotranspiration capacity. The $\mathrm{ET}_{\mathrm{c}}$ cold pattern looks very interesting, both for the present and future periods. The elevated values of the $\mathrm{ET}_{\mathrm{c} \text { cold }}$ are located especially in the areas covered by the mixed leaf associated trees, needle-leaved and deciduous forests, and evergreen forests which have the $\mathrm{K}_{\mathrm{c} \text { cold }}$ higher than 0.6 and the hilly and mountainous areas. In this season, the agriculture and urban lands indicate very low values (below $20 \mathrm{~mm}$ ) of the $\mathrm{ET}_{\mathrm{c} \text { cold }}$ due to the low temperatures, but in major cases the ET $_{\mathrm{c} \text { cold }}$ is $0 \mathrm{~mm}$ due to no value for the $\mathrm{K}_{\mathrm{c} \text { cold. }}$ In the cold months, due to the negative values of air temperature, the monthly index I of the Thornthwaite formula cannot return the positive values for the respective territories. Corrections of the index I raster data including the " 0 " values in that parcels was done with the aim to complete the ensemble of 12 months which served as the annual heat index I. These operations were needed because the seasonal and annual $\mathrm{ET}_{0}$ indicated "no data" in certain areas with low-temperature values, but in reality the $\mathrm{ET}_{0}$ is null there. Integrating the monthly heat index I and alpha parameter into the $\mathrm{ET}_{0}$ equation, the seasonal and annual $\mathrm{ET}_{0}$ and $\mathrm{ET}_{\mathrm{c}}$ were found. In broad terms, both annual $\mathrm{ET}_{0}$ and $\mathrm{ET}_{\mathrm{c}}$ have a correlated spatial distribution with the latitude and altitudes; moreover, good correlation exists between West and East, respectively the oceanity and continentality influences. Thus, on the southern and western sides of Europe, at low latitudes and closer to the Atlantic Ocean, the $\mathrm{ET}_{0}$ and $\mathrm{ET}_{\mathrm{c}}$ have high values, whereas on the northern and eastern sides, at high latitudes and close to the Asia continent, the $\mathrm{ET}_{0}$ and $\mathrm{ET}_{\mathrm{c}}$ have lower values. In the central parts of Europe, likely as a strike from West to East, the $\mathrm{ET}_{0}$ and $\mathrm{ET}_{\mathrm{c}}$ register medium values, slightly decreasing over the East. Comparing both maps, the details of the annual $\mathrm{ET}_{\mathrm{c}}$ indicates a more realistic situation of the European evapotranspiration because it incorporates the vegetation factor. As we expected for the British Islands, the annual $\mathrm{ET}_{\mathrm{c}}$ reaches values between 300 and $500 \mathrm{~mm}$, with decreasing spatial distribution from West to East due to the ocean air mass direction, but also the higher mean air temperature in the eastern areas. 
A significant observation should be made on the annual $\mathrm{ET}_{\mathrm{c}}$ in the urban areas and land with water bodies. Due to the low $\mathrm{K}_{\mathrm{c}}$ and no values of this coefficient during the cold season for the urban and water body lands, the annual map of $\mathrm{ET}_{\mathrm{c}}$ shows evapotranspiration amount below $200 \mathrm{~mm}_{\text {year }}{ }^{-1}$.

\section{Conclusions}

Overall, the seasonal and annual $\mathrm{ET}_{\mathrm{c}}$ in Europe were mapped for the 2011-2070 period, using long-term climate models and detailed CORINE Land Cover data. Variations of seasonal $\mathrm{ET}_{\mathrm{c}}$ values between the present and future are found for all four set stages, with significant increase in the mid-season and end season. The most striking seasonal findings refer to the $\mathrm{ET}_{\mathrm{c} \text { mid }}$ when the maximum values increase from $772 \mathrm{~mm}$ to $848 \mathrm{~mm}$ and the distribution of high values extends considerably in the area. Significant changes of the annual $\mathrm{ET}_{\mathrm{c}}$ could also be shown between the present and future periods. The annual $\mathrm{ET}_{\mathrm{c}}$ values increase from $1385 \mathrm{~mm}$ to $1496 \mathrm{~mm}$ due to the impact of climate change in the second half of the $21^{\text {st }}$ century.

Using the $\mathrm{K}_{\mathrm{c}}$ and climate models, the present study shows a reliable approach to assessing the $\mathrm{ET}_{\mathrm{c}}$ at the spatial level even if the crop calendar may have some overlapping times due to the cultivations and complexity of vegetation development in the European continent. Nistor and Porumb-Ghiurco (2015) and Nistor et al. (2017a) illustrated in their studies how the methodology at a regional scale works.

Based on the findings, the impact of climate change indicates a negative aspect in terms of drought and water availability in several areas of Europe. The southern, western, southeastern, and central sides of Europe are faced with the high annual $\mathrm{ET}_{\mathrm{c}}$ (over $1000 \mathrm{~mm} \mathrm{year}^{-1}$ ), a fact which may produce problems on the surface and groundwater resources, also a slight desertification may also occur in those areas. Even if few, the important areas with low annual $\mathrm{ET}_{\mathrm{c}}$ were found in the Alps Range, Pyrenees Range, Caucasus Range, Scandinavian Peninsula, western and northern sides of the British Islands, centre of France and sparse parts of East Europe. These areas are not drastically affected by global warming and can be a considerable source of water supply. In this sense, our work highlights the spatial variation of evapotranspiration under climate change. The findings could be important keys for the scientists in climatology, hydrology, and agriculture. Moreover, the maps made in this survey represent a tool for urban and environmental planning, water resources and land irrigation strategies, reports and further scenarios of derivate indices regarding the land use policy and climate change mitigation. We strongly recommend to complete more investigations of water availability in the areas where the annual $\mathrm{ET}_{\mathrm{c}}$ exceed $1000 \mathrm{~mm}_{\text {year }}{ }^{-1}$, especially in the southern, western, southeastern, and central sides of Europe. The investigation of these areas should include groundwater monitoring and vulnerability assessment to climate change. Surface waters quality evaluation through in-situ methods (water sampling from rivers, irrigation channels) in the South of Europe will allow providing sustainable water resources and durable ecosystems. The aquifers located near the coastal areas are supposed to be in danger due to sea level rise and seawater intrusions. For a proper management and sustainable groundwater resources in the coastal areas, we suggest to each region to complete temporal water sample analysis (once two years) regarding the salinity variation and to organize workshops to provide solutions for fresh water sustainability in the regions where the salinity in groundwater increases. 
Acknowledgements. The authors thank the European Environment Agency, which provided the land cover data for the whole of Europe, and to Andreas Hamann from Alberta University for the climate models data.

\section{REFERENCES}

[1] Allen, R. G. (2000): Using the FAO-56 dual crop coefficient method over an irrigated region as part of an evapotranspiration intercomparison study. - Journal of Hydrology 229: 27-41.

[2] Allen, R. G., Pereira, L. S., Raes, D., Smith, M. (1998): Crop evapotranspiration: guidelines for computing crop water requirements. - FAO Irrigation and Drainage Paper 56, Rome.

[3] Ambas, V. T., Baltas, E. (2012): Sensitivity analysis of different evapotranspiration methods using a new sensitivity coefficient. - Global NEST Journal 14(3): 335-343.

[4] Anda, A., Soos, G., Teixeira da Silva, J. A., Kozma-Bognar, V. (2015): Regional evapotranspiration from a wetland in Central Europe, in a 16-year period without human intervention. - Agricultural and Forest Meteorology 205: 60-72.

[5] Bachu, S., Adams, J. J. (2003): Sequestration of CO2 in geological media in response to climate change: capacity of deep saline aquifers to sequester $\mathrm{CO} 2$ in solution. - Energy Conversion and Management 44: 3151-3175.

[6] Baltas, E. (2007): Spatial distribution of climatic indices in the northern Greece. Meteorological Applications 14: 69-78.

[7] Blanka, V., Ladányi, Zs., Szilassi, P., Sipos, G., Rácz, A., Szatmári, J. (2017): Public perception on hydro-climatic extremes and water management related to environmental exposure, SE Hungary. - Water Resources Management 31: 1619-1634. DOI: 10.1007/s11269-017-1603-z.

[8] Brouyère, S., Carabin, G., Dassargues, A. (2004): Climate change impacts on groundwater resources: modelled deficits in a chalky aquifer, Geer basin, Belgium. Hydrogeology Journal 12: 123-134.

[9] Campos, G. E. P., Moran, M. S., Huete, A., Zhang, Y., Bresloff, C., Huxman, T. E. et al. (2013): Ecosystem resilience despite large-scale altered hydroclimatic conditions. Nature 494: 349-353.

[10] Čenčur Curk, B., Cheval, S., Vrhovnik, P., Verbovšek, T., Herrnegger, M., Nachtnebel, H. P., Marjanović, P., Siegel, H., Gerhardt, E., Hochbichler, E., Koeck, R., Kuschnig, G., Senoner, T., Wesemann, J., Hochleitner, M., Žvab Rožič, P., Brenčič, M., Zupančič, N., Bračič Železnik, B., Perger, L., Tahy, A., Tornay, E. B., Simonffy, Z., Bogardi, I., Crăciunescu, A., Bilea, I. C., Vică, P., Onuţu, I., Panaitescu, C., Constandache, C., Bilanici, A., Dumitrescu, A., Baciu, M., Breza, T., Marin, L., Draghici, C., Stoica, C., Bobeva, A., Trichkov, L., Pandeva, D., Spiridonov, V., Ilcheva, I., Nikolova, K., Balabanova, S., Soupilas, A., Thomas, S., Zambetoglou, K., Papatolios, K., Michailidis, S., Michalopoloy, C., Vafeiadis, M., Marcaccio, M., Errigo, D., Ferri, D., Zinoni, F., Corsini, A., Ronchetti, F., Nistor, M. M., Borgatti, L., Cervi, F., Petronici, F., Dimkić, D., Matić, B., Pejović, D., Lukić, V., Stefanović, M., Durić, D., Marjanović, M., Milovanović, M., Boreli-Zdravković, D., Mitrović, G., Milenković, N., Stevanović, Z., Milanović, S. (2014): CC-WARE Mitigating Vulnerability of water resources under climate change. WP3 - Vulnerability of Water Resources in SEE. Report Version 5. http://www.ccware.eu/output-documentation/output-wp3.html.

[11] Cheval, S., Dumitrescu, A., Barsan, M. V. (2017): Variability of the aridity in the SouthEastern Europe over 1961-2050. - Catena 151: 74-86.

[12] Daly, C. (2006): Guidelines for assessing the suitability of spatial climate data sets. - Int. J. Climatol. 26: 707-721. 
[13] Dezsi, Şt., Nistor, M. M., Man, T. C., Rusu, R. (2015): The GIS assessment of a winter sports resort location. Case study: Beliş District, Western Carpathians. - Carpathian Journal of Earth and Environmental Sciences 10(1): 223-230.

[14] Dong, P., Wang, C., Ding, J. (2013): Estimating glacier volume loss used remotely sensed images, digital elevation data, and GIS modelling. - International Journal of Remote Sensing 34(24): 8881-8892.

[15] European Environment Agency. (2007): The Pannonian Region - the Remains of the Pannonian Sea. [Condé, S., Richard, D., Liamine, N., Leclère, A. S., Sotolargo, B., Pinborg, U. (eds.)]. - ZooBoTech HB, Lund, Sweden.

[16] European Environment Agency. (2016): Report on "Raster data on land cover for the CLC2000 inventory". - Copenhagen, Denmark.

[17] Fiala, K., Blanka, V., Ladányi, Z., Szilassi, S., Benyhe, B., Dolinaj, D., Pálfai, I. (2014): Drought Severity and its Effect on Agricultural Production in the Hungarian-Serbian Cross-Border Area. - Journal of Environmental Geography 7(3-4): 43-51.

[18] Figura, S., Livingstone, D. M., Hoehn, E., Kipfer, R. (2011): Regime shift in groundwater temperature triggered by the Arctic Oscillation. - Geophys. Res. Lett. 38(L23401): 1-5. doi.org/10.1029/2011GL049749.

[19] Gowda, P. H., Chavez, J. L., Colaizzi, P. D., Evett, S. R., Howell, T. A., Tolk, J. A. (2008): ET mapping for agricultural water management: present status and challenges. Irrig. Sci. 26(3): 223-237.

[20] Güçlü, Y. S., Subyani, A. M., Şen, Z. (2017): Regional fuzzy chain model for evapotranspiration estimation. - Journal of Hydrology 544: 233-241.

[21] Grimmond, C. S. B., Oke, T. R. (1999): Evapotranspiration rates in urban areas, impacts of urban growth on surface water and groundwater quality. - Proceedings of IUGG 99 Symposium HSS. Birmingham, July J999. IAHS. publ. no. 259, pp. 235-243.

[22] Haeberli, W. R., Frauenfelder, R., Hoelzle, M., Maisch, M. (1999): On rates and acceleration trends of global glacier mass changes. - Physical Geography 81A: 585-595.

[23] Haldorsen, S., Heim, M., van der Ploeg, M. (2012): Impacts of Climate Change on Groundwater in Permafrost Areas - Case Study from Svalbard, Norway: 323-340. - In: Treidel, H,. Martin-Bordes, J. J., Gurdak, J. J. (eds.) Climate Change Effects on Groundwater Resources: A Global Synthesis of Findings and Recommendations International Association of Hydrogeologists (IAH). International Contributions to Hydrogeology. Taylor \& Francis, London.

[24] Hamann, A., Wang, T. L. (2005): Models of climatic normals for genecology and climate change studies in British Columbia. - Agricultural and Forest Meteorology 128: 211221.

[25] Hamann, A., Wang, T., Spittlehouse, D. L., Murdock, T. Q. (2013): A comprehensive, high-resolution database of historical and projected climate surfaces for western North America. - Bulletin of the American Meteorological Society 94: 1307-1309.

[26] IPCC (1996): Climate Change 1995: The Science of Climate Change. Contribution of Working Group I to the Second Assessment Report of the Intergovernmental Panel on Climate Change [Houghton, J. T., Meira Filho, L. G., Callander, B. A., Harris, N., Kattenberg, A., Maskell, K. (eds.)]. - Cambridge University Press, Cambridge, UK.

[27] IPCC (2001): Climate Change 2001: The Scientific Basis. Contribution of Working Group I to the Third Assessment Report of the Intergovernmental Panel on Climate Change [Houghton, J. T., Ding, Y., Griggs, D. J., Noguer, M., van der Linden, P. J., Dai, X., Maskell, K., Johnson, C. A. (eds.)]. - Cambridge University Press, Cambridge, UK.

[28] IPCC (2007): Climate Change 2007: Impacts, Adaptation and Vulnerability. Contribution of Working Group II to the Fourth Assessment Report of the Intergovernmental Panel on Climate Change [Parry, M. L., Canziani, O. F., Palutikof, J. P., van der Linden, P. J., Hanson, C. E. (Eds.)]. - Cambridge University Press, Cambridge, UK.

[29] Jiménez Cisneros, B. E., Oki, T., Arnell, N. W., Benito, G., Cogley, J. G., Döll, P., Jiang, T., Mwakalila, S. S. (2014): Freshwater Resources. - In: Field, C. B., Barros, V. R., 
Dokken, D. J., Mach, K. J., Mastrandrea, M. D., Bilir, T. E., Chatterjee, M., Ebi, K. L., Estrada, Y. O., Genova, R. C., Girma, B., Kissel, E. S., Levy, A. N., MacCracken, S., Mastrandrea, P. R., White, L. L. (eds.). Climate Change 2014: Impacts, Adaptation, and Vulnerability. Part A: Global and Sectoral Aspects. Contribution of Working Group II to the Fifth Assessment Report of the Intergovernmental Panel on Climate Change, pp. 229269. Cambridge University Press, Cambridge, UK.

[30] Kargel, J. S., Abrams, M. J., Bishop, M. P., Bush, A., Hamilton, G., Jiskoot, H., Kääb, A., Kieffer, H. H., Lee, E. M., Paul, F., Rau, F., Raup, B., Shroder, J. F., Soltesz, D., Stainforth, S., Stearns, L., Wessels, R. (2005): Multispectral imaging contributions to global land ice measurements from space. - Remote Sensing of Environment 99(1): 187219.

[31] Kløve, B., Ala-Aho, P., Okkonen, J., Rossi, P. (2012): Possible Effects of Climate Change on Hydrogeological Systems: Results From Research on Esker Aquifers in Northern Finland, pp. 305-322. - In: Treidel, H., Martin-Bordes, J. J., Gurdak, J. J. (eds.) Climate Change Effects on Groundwater Resources: A Global Synthesis of Findings and Recommendations. International Association of Hydrogeologists (IAH) International Contributions to Hydrogeology. Taylor \& Francis Publishing, London.

[32] Kløve, B., Ala-Aho, P., Bertrand, G., Gurdak, J. J., Kupfersberger, H., Kværner, J., Muotka, T., Mykrä, H., Preda, E., Rossi, P., Bertacchi Uvo, C., Velasco, E., PulidoVelazquez, M. (2014): Climate change impacts on groundwater and dependent ecosystems. - Journal of Hydrology 518: 250-266.

[33] Kottek, M., Grieser, J., Beck, C., Rudolf, B., Rubel, F. (2006): World Map of the Köppen-Geiger climate classification updated. - Meteorologische Zeitschrift 15(3): 259263.

[34] Kurnik, B., Kajfež-Bogatajb, L., Horionc, S. (2014): An assessment of actual evapotranspiration and soil water deficit in agricultural regions in Europe. - Int. J. Climatol. DOI: $10.1002 /$ joc.4154.

[35] Ladányi, Zs., Blanka, V., Meyer, B., Mezősi, G., Rakonczai, J. (2015): Multi-indicator sensitivity analysis of climate change effects on landscapes in the Kiskunság National Park, Hungary. - Ecological Indicators 58: 8-20.

[36] Li, K. Y., Coe, M. T., Ramankutty, N., De Jong, R. (2007): Modeling the hydrological impact of land-use change inWest Africa. - Journal of Hydrology 337: 258-268.

[37] Loàiciga, H. A., Maidment, D. R., Valdes, J. B. (2000): Climate-change impacts in a regional karst aquifer, Texas, USA. - Journal of Hydrology 227: 173-194.

[38] Mbogga, M. S., Hamann, A., Wang, T. (2009): Historical and projected climate data for natural resource management in western Canada. - Agricultural and Forest Meteorology 149: 881-890.

[39] Mitchell, T. D., Jones, P. D. (2005): An improved method of constructing a database of monthly climate observations and associated high-resolution grids. - Int. J. Climatol. 25: 693-712.

[40] Mojid, M. A., Rannu, R. P., Karim, N. N. (2015): Climate change impacts on reference crop evapotranspiration in North-West hydrological region of Bangladesh. - Int. J. Climatol. 35(13): 4041-4046. DOI: 10.1002/joc.4260.

[41] Nistor, M. M. (2013): Geological and geomorphological features of Kenai and Chugach Mountains in Whittier Area, Alaska. - Studia UBB Geographia LVIII(1): 27-34.

[42] Nistor, M. M. (2014): Using Landsat images and GIS to assess the changes of Mer de Glace and Marmolada Glaciers, in the last three decades. - Studia UBB Geographia LIX(1): 65-76.

[43] Nistor, M. M. (2016a): Mapping evapotranspiration coefficients in the Paris metropolitan area. - GEOREVIEW Scientific Annals of Ştefan cel Mare University of Suceava Geography Series 26(1): 138-153. 
[44] Nistor, M. M. (2016b): Seasonal Analysis of Crop Evapotranspiration Based on PenmanMonteith Equation in Po River Delta, Italy. - In: Pittman, G. (ed.). Italy: Economic, Social and Environmental Issue. Nova Science Publishers, New York.

[45] Nistor, M. M. (2017): Climate change impact on glaciers retreat in Passage Canal fjord, Alaska. - Carpathian Journal of Earth and Environmental Sciences 12(1): 259-267.

[46] Nistor, M. M., Mîndrescu, M. (2017): Climate change effect on groundwater resources in Emilia-Romagna region: An improved assessment through NISTOR-CEGW method. Quaternary International. https://doi.org/10.1016/j.quaint.2017.11.018.

[47] Nistor, M. M., Petcu, I. M. (2014): The role of glaciers in the evolution of Prince William Sound landscape ecosystems, Alaska. - Studia UBB Ambientum LIX(1-2): 97-109.

[48] Nistor, M. M., Petcu, I. M. (2015): Quantitative analysis of glaciers changes from Passage Canal based on GIS and satellite images, South Alaska. - Applied Ecology and Environmental Research 13(2): 535-549.

[49] Nistor, M. M., Porumb-Ghiurco, G. C. (2015): How to compute the land cover evapotranspiration at regional scale? A spatial approach of Emilia-Romagna region. GEOREVIEW Scientific Annals of Ştefan cel Mare University of Suceava Geography Series 25(1): 38-54.

[50] Nistor, M. M., Ronchetti, F., Corsini, A., Cervi, F., Borgatti, L., Errigo, D., Marcaccio, M. (2014): Vulnerability of groundwater in fractured aquifers, under climate and land use change in Northern Apennines. - National Meeting on Hydrogeology, Abstract volume Flowpath 2014, Viterbo June 18-20, pp. 152-153 (ISBN 978-88-907553-4-7).

[51] Nistor, M. M., Dezsi, S,., Cheval, S. (2015): Vulnerability of groundwater under climate change and land cover: a new spatial assessment method applied on Beliş district (Western Carpathians, Romania). - Environmental Engineering and Management Journal 14(12): 2959-2971.

[52] Nistor, M. M., Gualtieri, A., Cheval, S., Dezsi, Șt., Boţan, V. E. (2016): Climate change effects on crop evapotranspiration in the Carpathian Region during 1961-2010. Meteorological applications 23: 462-469.

[53] Nistor, M. M., Ronchetti, F., Corsini, A., Cheval, S., Dumitrescu, A., Kumar Rai, P., Petrea, D., Dezsi, Şt. (2017a): Crop evapotranspiration variation under climate change in South East Europe during 1991-2050. - Carpathian Journal of Earth and Environmental Sciences 12(2): 571-582.

[54] Nistor, M. M., Cheval, S., Gualtieri, A., Dumitrescu, A., Boţan, V. E., Berni, A., Hognogi, G., Irimuş, I. A., Porumb-Ghiurco, C. G. (2017b): Crop evapotranspiration assessment under climate change in the Pannonian basin during 1991-2050. Meteorological applications 24: 84-91.

[55] Oerlemans, J. (2005): Extracting a climate signal from 169 glacier records. - Science 308: 675-677.

[56] Parmesan, C., Yohe, G. (2003): A globally coherent fingerprint of climate change impacts across natural systems. - Nature 421(2): 37-42.

[57] Piao, S., Ciais, P., Huang, Y., Shen, Z., Peng, S., Li, J., Zhou, L., Liu, H., Ma, Y., Ding, Y., Friedlingstein, P., Liu, C., Tan, K., Yu, Y., Zhang, T., Fang, J. (2010): The impacts of climate change on water resources and agriculture in China. - Nature 467(7311): 43-51.

[58] Prăvălie, R., Sîrodoev, I., Peptenatu, D. (2014): Detecting climate change effects on forest ecosystems in Southwestern Romania using Landsat TM NDVI data. - Journal of Geographical Sciences 24: 815-832.

[59] Ramírez-Cuesta, J. M., Cruz-Blanco, M., Santos, C., Lorite, I. J. (2017): Assessing reference evapotranspiration at regional scale based on remote sensing, weather forecast and GIS tools. - International Journal of Applied Earth Observation and Geoinformation 55: $32-42$.

[60] Rosenberry, D. O., Winter, T. C., Buso, D. C., Likens, G. E. (2007): Comparison of 15 evaporation methods applied to a small mountain lake in the northeastern USA. - Journal of Hydrology 340: 149-166. 
[61] Stavig, L., Collins, L., Hager, C., Herring, M., Brown, E., Locklar, E. (2005): The effects of climate change on Cordova, Alaska on the Prince William Sound. Alaska Tsunami Papers. - The National Ocean Sciences Bowl. https://seagrant.uaf.edu/nosb/papers/2005/cordova-nurds.html (accessed 23 April 2014).

[62] Taylor, C. A., Stefan, H. G. (2009): Shallow groundwater temperature response to climate change and urbanization. - Journal of Hydrology 375(3-4): 601-612.

[63] The Canadian Centre for Climate Modelling and Analysis. (2014): The first generation coupled global climate model publishing web. - http://www.ec.gc.ca/ccmacccma/default.asp?lang=En\&n=540909E4-1 (accessed 20 March 2015).

[64] Thornthwaite, C. W. (1948): An approach toward a rational classification of climate. Geogr. Rev. 38: 55-94.

[65] Zhan, C., Yin, J., Wang, F., Dong, Q. (2015): Regional estimation and validation of remotely sensed evapotranspiration in China. - Catena 133: 35-42. 